\title{
Growth and slaughter characteristics of Ankole cattle and its Boran and Friesian crossbreds
}

\author{
D. Asizua ${ }^{1}$, D. Mpairwe ${ }^{1 \#}$, F. Kabi ${ }^{1}$, D. Mutetikka ${ }^{1}$ and J. Madsen ${ }^{2}$ \\ ${ }^{1}$ Department of Animal Science, Faculty of Agriculture, Makerere University, P.O. Box 7062, Kampala, Uganda \\ ${ }^{2}$ Department of Large Ruminant Production, University of Life Sciences, Copenhagen, Denmark
}

\begin{abstract}
One hundred and forty four bulls comprising 48 animals of each breed, i.e. purebred Ankole (ANK) and its crossbreds with Boran (AXB) and Friesian (AXF) were assigned to three feeding systems (FS) to evaluate their performance for improved beef production. The bulls, averaging $191 \pm 9.6 \mathrm{~kg}$ live weight and 18 months of age, were arranged in a completely randomized design in a $3 \times 3$ factorial treatment arrangement. The feeding systems comprised: T1 (Grazing alone), T2 (Grazing + concentrate) and T3 (feedlot finishing with maize stover plus $60 \%$ concentrate fed ad libitum). Both genotype and feeding system affected growth and slaughter characteristics. The AXF crossbreds had higher average daily gain (ADG) (620 g/day) than ANK (560 g/day) and AXB (500 g/day). Average daily gain was higher in T3 (850 g/day) than in T2 (550 g/day) and T1 (270 g/day). Hot carcass weight and dressing percentage varied in a descending order of 145, 132, $110 \mathrm{~kg}$ and 52, 51 and 50\% for T3, T2 and T1, respectively. Similar trends were observed for non-carcass components although there were no differences between T3 and T2. Except for external non-carcass components, genotype did not affect slaughter characteristics. The results of this study indicated that the indigenous Ankole cattle have a great potential for beef production when finished in a feedlot even without crossbreeding.
\end{abstract}

Keywords: Indigenous cattle, feedlot, performance

\# Corresponding author. E-mail: dmpairwe@agric.mak.ac.ug

\section{Introduction}

Uganda's beef industry has for long relied on indigenous cattle genotypes raised under extensive management systems, in the rangelands. The Ankole cattle which constitute more than half of the indigenous cattle population are a key component of the livelihood of pastoral communities. However, with increasing interest in dairy and improved beef production, crossbreeding with Friesian and improved Boran breeds is growing. The Ministry of Agriculture Animal Industry and Fisheries estimated the exotic/crossbred cattle population at 1.3 million, accounting for $17.3 \%$ of the total cattle population (about 7.6 million) in the country (MAAIF, 2006) compared to 4.4\% in 1997. This exposes the indigenous cattle population to further threats of extinction. A few studies have evaluated the performance of the Anloke cattle for improved beef production (Kabi, 2003; Mpairwe et al., 2003) but concentrated on nutritional management. Other studies have concentrated on milk production potential (Grimaud, 2007; Hatungumukama, 2007), grazing behaviour (Huber et al., 2008) and fitness traits (Ndumu et al., 2008).

The Ankole cattle have also been victims of the overall perception that indigenous tropical cattle breeds have low potential for improved beef production. But the successes achieved in the South African beef industry through use of Nguni cattle (Strydom, 2008; Strydom et al., 2008) bears commendable evidence for utilisation of these animals for beef production. This study was conducted to test whether the Ankole cattle and its crossbreds with Boran and Friesian are not similar in performance under supplementation of the traditional grazing system and feedlot finishing.

\section{Materials and Methods}

The study was conducted between July and December, 2007 on a private ranch located in Nakaseke district which lies within the cattle corridor of Uganda at an altitude of $1080 \mathrm{~m}$ and latitude $1^{\circ} 0$ " 0 ' North and longitude $32^{\circ} 19^{\prime \prime} 60^{\prime}$ East. Total mean annual rainfall ranges between 800 - $1233 \mathrm{~mm}$. Total rainfall for 2007 was $1263 \mathrm{~mm}$ while rainfall between July and December was $639 \mathrm{~mm}$. The area is characterized by open dry savannah with Combretum spp. as the main tree species and sparsely distributed Acacia spp. 
A 3 X 3 factorial treatment structure was used to randomly allocate 144 young bulls $(191 \pm 9.6 \mathrm{~kg}$ initial weight); 48 pure Ankole (ANK), 48 Ankole-Boran (AXB) and 48 Ankole-Friesian (AXF) crossbreds aged 18 months on average, to three feeding systems: solely grazing (control, T1), grazing with concentrate supplementation overnight (T2) and fully confined feedlot finishing (T3) with bulls fed ad libitum on maize stover and concentrate. The grazing pastures comprised of Sporobollus spp., Brachiaria spp., Cymbopogon spp., Themeda spp., Panicum spp., Chloris spp. and Hyparrhenia spp. sparsely distributed in open dry savannah. The concentrate comprised $70 \%$ maize bran, $20 \%$ cotton seedcake and $10 \%$ molasses. All bulls had free access to rock salt and water. Daily feed offer included an additional 10\% of previous day's intake per pen of four bulls and concentrate accounted for $60 \%$ of the daily offer for bulls in T3. The trial lasted for 120 days excluding a 28 day adaptation period.

Grazing bulls were released to graze by 08:30 and the grazing supplemented group returned for concentrate feeding by 17:30. Concentrate in T3 was offered in two equal proportions at 08:30 and 16:30 while maize stover chopped at less than $6 \mathrm{~cm}$ lengths was offered in small batches throughout the day.

Bulls were weighed in three consecutive days to establish initial weights. Subsequent weights were taken every 14 days. All weights were taken before a day's morning offer of feeds. Average daily live body weight gain was determined as a proportion of total weight change over the period on feed (120 days). At the end of the feeding trial, eight bulls per treatment were selected for slaughter. Bulls were transported for eight hours to a commercial abattoir located about $120 \mathrm{~km}$ from the ranch and were slaughtered after an overnight fasting. Measurements taken at slaughter included: slaughter weights and hot carcass weights, and hot carcass dressing percentage were computed as a percentage of the hot carcass weight to the slaughter weight. Weights of skin with tail, feet, heart, lungs with trachea, kidney without fat, liver with gall bladder, empty stomach (rumen, reticulum, omasum and abomasum) and empty intestines (small and large intestines) with caecum were taken and recorded as non-carcass components. Omental fat, mesenteric fat, kidney fat, pericardial fat and scrotal fat were also weighed and recorded. Omental and mesenteric fat were summed as digestive tract fat while kidney and cardiac fat were summed as pluck fat. Total internal fat was computed as the sum of the digestive tract fat and pluck fat.

Maize stover and concentrate sub-samples were collected per batch of chopping and mixing respectively and each merged to form monthly samples for chemical analysis. Pasture samples were collected each month through on spot observation of the grazing behaviour of bulls and herbage samples cut in close simulation of the height of harvest by bulls at random sites in the grazing area. Dry matter (DM), crude protein (CP), ether extracts (EE), calcium (Ca), phosphorus (P) and total ash were analysed according to the procedures of AOAC (1990). Neutral detergent fibre (NDF), acid detergent fibre (ADF) and acid detergent lignin (ADL) were analysed by the procedures of Van Soest et al. (1991). Gross energy (GE) was analysed using the bomb calorimeter (GALLENKAMP Autobomb, UK).

Data was analysed using the general linear model (GLM) procedures of Statistical Analysis Systems (SAS, 2003) using a factorial treatment arrangement. The least square means generated were separated using standard error of the mean and the probability of difference between means.

\section{Results and Discussion}

The chemical composition of the concentrate supplement, maize stover and pastures are presented in Table 1. Gross energy, crude protein and ether extracts were higher in concentrate supplement than pasture and maize stover in that order.

The Least squares means for effects of genotype and feeding system on growth performance are presented in Table 2. Genotype affected average daily gain (ADG), live weight change (LWC) and final live weight (FLW), but not $(\mathrm{P}>0.05)$ genotype-feeding system interaction. The AXF had higher $(\mathrm{P}<0.05) \mathrm{ADG}$, LWC and FLW than the AXB. The ANK bulls had similar (P >0.05) ADG, LWC and final weight to that of AXF and AXB. The higher growth rate of the AXF could be attributed to their large frame and heavier mature size (Owens et al., 1993).

Feeding system significantly affected growth performance (Table 2). Bulls in the feedlot (T3) had a faster $(\mathrm{P}<0.001)$ growth rate than the grazing and supplemented (T2) and sole grazing (T1) bulls. The corresponding mean weight gains were $0.85,0.55,0.27 \mathrm{~kg} /$ head/day for $\mathrm{T} 3$, $\mathrm{T} 2$ and $\mathrm{T} 1$, respectively. The higher growth rate in the supplemented bulls (T3 and T2) was attributed to the higher energy and protein intake from the concentrate supplement. 
Table 1 Chemical composition (g/kg DM) of feeds with standard deviation

\begin{tabular}{lrrr}
\hline & Concentrate & \multicolumn{1}{c}{ Maize stover } & \multicolumn{1}{c}{ Pasture } \\
\hline & & & \\
Dry matter & $905 \pm 4.4$ & $889 \pm 22.5$ & $879 \pm 9.4$ \\
Gross energy (MJ/kg DM) & $17.4 \pm 0.6$ & $15.2 \pm 1.0$ & $15.3 \pm 0.9$ \\
Crude protein & $150.8 \pm 9.9$ & $53.0 \pm 6.7$ & $90.0 \pm 11.9$ \\
Neutral detergent fibre & $285.5 \pm 13.8$ & $692.6 \pm 34.2$ & $558.1 \pm 22.7$ \\
Acid detergent fibre & $76.0 \pm 5.0$ & $405.6 \pm 18.9$ & $346.6 \pm 16.1$ \\
Acid detergent lignin & $26.4 \pm 0.7$ & $63.2 \pm 5.1$ & $59.2 \pm 5.4$ \\
Ether extract & $94.2 \pm 3.8$ & $4.2 \pm 0.6$ & $9.8 \pm 1.6$ \\
Ash & $52.2 \pm 2.2$ & $103.5 \pm 6.1$ & $80.2 \pm 4.7$ \\
Calcium & $1.5 \pm 0.2$ & $0.3 \pm 0.05$ & $4.5 \pm 1.2$ \\
Phosphorus & $4.2 \pm 0.4$ & $7.8 \pm 0.9$ & $8.2 \pm 1.1$ \\
& & & \\
\hline
\end{tabular}

Table 2 Least squares means for growth performance as affected by genotype (Gen) and feeding systems (FS)

\begin{tabular}{lccccccccccc}
\hline & \multicolumn{3}{c}{ Genotype } & \multicolumn{3}{c}{ Feeding system } & \multicolumn{3}{c}{ Significance } \\
\cline { 2 - 11 } & ANK & AXB & AXF & s.e. & T1 & T2 & T3 & s.e. & Gen & FS \\
\hline Initial weight (kg) & 185.4 & 202.0 & 185.2 & 8.4 & 199.7 & 197.2 & 175.7 & 8.4 & ns & ns \\
Final Weight (kg) & $258.1^{\text {ab }}$ & $251.2^{\mathrm{b}}$ & $265.8^{\mathrm{a}}$ & 3.5 & $223.6^{\mathrm{c}}$ & $257.5^{\mathrm{b}}$ & $293.9^{\mathrm{a}}$ & 3.3 & $*$ & $* * *$ \\
Weight change (kg) & $66.7^{\mathrm{ab}}$ & $59.8^{\mathrm{b}}$ & $74.4^{\mathrm{a}}$ & 3.5 & $32.2^{\mathrm{c}}$ & $66.1^{\mathrm{b}}$ & $102.5^{\mathrm{a}}$ & 3.3 & $*$ & $* * *$ \\
Average daily gain (kg) & $0.56^{\mathrm{ab}}$ & $0.50^{\mathrm{b}}$ & $0.62^{\mathrm{a}}$ & 0.30 & $0.27^{\mathrm{c}}$ & $0.55^{\mathrm{b}}$ & $0.85^{\mathrm{a}}$ & 0.03 & $*$ & $* * *$
\end{tabular}

ANK - Ankole; AXB - Ankole-Boran; AXF - Ankole-Friesian.

a, b, c Means within rows with different superscripts differ $(\mathrm{P}<0.05)$; ***- $\mathrm{P}<0.001$; *-P <0.05; ns-non significant.

s.e. - Standard error of the mean.

Results for slaughter characteristics are presented in Tables 3. Genotype and genotype-feeding system interaction did not affect $(\mathrm{P}>0.05)$ slaughter weight, empty body weight, hot carcass weight and hot carcass dressing percentage. Genotype, however, affected some non-carcass components such as skin plus tail and scrotal fat $(\mathrm{P}<0.01)$, feet $(\mathrm{P}<0.05)$ and total gastrointestinal tract $(\mathrm{GIT})(\mathrm{P}<0.01)$. Heavier skin plus tail were also obtained in the ANK and AXB bulls than the AXF and this was associated with the dewlap, large umbilical flap and extra skin covering humps which significantly contribute to the weight of the skin in indigenous tropical cattle breeds. The AXF bulls had heavier weights of feet than ANK and AXB and this was attributed to their larger frame size as was noted by Owens et al. (1993).

Feeding system affected $(\mathrm{P}<0.001)$ slaughter weight, hot carcass weight and hot carcass percentage ( $\mathrm{P}<0.05)$. Skin plus tail, feet, heart, liver, lungs, kidney, spleen, scrotal fat, internal fat were also affected by feeding system. Supplemented bulls (T3 and T2) had heavier body parts than control bulls (grazing alone, T1) and this was attributed to deposition of protein and energy in growing animals which according to Geay (1984) and Webster (1986) increases with increasing levels of supply of these two nutrients.

\section{Conclusion}

The lack of statistical difference between the pure bred Ankole cattle ANK and AXF on growth characteristics reflects the potential of the genotype for beef production without crossbreeding. The increasing performance of bulls with increasing level of management and nutrient supply reveals that the achieved performance levels in this study were lower than the true potential of these genotypes when subjected to ad libitum nutrient supply. 
Table 3 Least squares means for the slaughter characteristics of the different feeding systems and genotypes

\begin{tabular}{|c|c|c|c|c|c|c|c|c|c|c|}
\hline & \multicolumn{3}{|c|}{ Genotype (Gen) } & \multicolumn{5}{|c|}{ Feeding system (FS) } & \multicolumn{2}{|c|}{ Significance } \\
\hline & ANK & AXB & AXF & s.e. & T1 & $\mathrm{T} 2$ & T3 & s.e. & Gen & FS \\
\hline \multicolumn{11}{|l|}{ Carcass components } \\
\hline Slaughter weight & 248.7 & 250.2 & 255.0 & 3.8 & $220.2^{\mathrm{c}}$ & $257.1^{\mathrm{b}}$ & $276.5^{\mathrm{a}}$ & 4.0 & ns & $* * *$ \\
\hline Hot carcass weight & 126.7 & 129.3 & 130.8 & 2.4 & $109.6^{\mathrm{c}}$ & $132.3^{\mathrm{b}}$ & $145.0^{\mathrm{a}}$ & 2.5 & ns & $* * *$ \\
\hline Hot carcass dressing \% & 50.9 & 51.6 & 51.2 & 0.6 & $49.9^{\mathrm{b}}$ & $51.4^{\mathrm{ab}}$ & $52.3^{\mathrm{a}}$ & 0.6 & ns & * \\
\hline \multicolumn{11}{|c|}{ External non-carcass components } \\
\hline Skin plus tail & $22.9^{\mathrm{b}}$ & $25.0^{\mathrm{a}}$ & $20.0^{c}$ & 0.61 & $19.8^{\mathrm{c}}$ & $22.3^{\mathrm{b}}$ & $25.9^{\mathrm{a}}$ & 0.64 & $* * *$ & $* * *$ \\
\hline Feet & $6.6^{\mathrm{b}}$ & $6.5^{\mathrm{b}}$ & $6.9^{\mathrm{a}}$ & 0.09 & $6.2^{\mathrm{c}}$ & $6.7^{\mathrm{b}}$ & $7.2^{\mathrm{a}}$ & 0.1 & $* *$ & $* * *$ \\
\hline \multicolumn{11}{|c|}{ Internal non-carcass components } \\
\hline Heart & 1.1 & 1.1 & 1.2 & 0.03 & $1.02^{\mathrm{b}}$ & $1.14^{\mathrm{a}}$ & $1.20^{\mathrm{a}}$ & 0.03 & ns & $* * *$ \\
\hline Liver & $4.0^{\mathrm{b}}$ & $4.1^{\mathrm{ab}}$ & $4.4^{\mathrm{a}}$ & 0.12 & $3.58^{\mathrm{b}}$ & $4.30^{\mathrm{a}}$ & $4.57^{\mathrm{a}}$ & 0.12 & $*$ & $* * *$ \\
\hline Lungs & 4.5 & 4.5 & 4.7 & 0.16 & $3.98^{\mathrm{b}}$ & $4.67^{\mathrm{a}}$ & $4.97^{\mathrm{a}}$ & 0.15 & ns & $* * *$ \\
\hline Kidney & 0.69 & 0.66 & 0.68 & 0.02 & $0.56^{\mathrm{b}}$ & $0.62^{\mathrm{b}}$ & $0.85^{\mathrm{a}}$ & 0.022 & ns & $* * *$ \\
\hline Spleen & 0.72 & 0.66 & 0.64 & 0.03 & $0.55^{\mathrm{b}}$ & $0.71^{\mathrm{a}}$ & $0.76^{\mathrm{a}}$ & 0.025 & ns & $* * *$ \\
\hline Total GIT ${ }^{1}$ & $19.4^{\mathrm{b}}$ & $19.8^{b}$ & $21.2^{\mathrm{a}}$ & 0.47 & $19.3^{\mathrm{b}}$ & $20.7^{\mathrm{a}}$ & $20.4^{\mathrm{ab}}$ & 0.43 & $*$ & ns \\
\hline Internal fat ${ }^{2}$ & 3.4 & 3.9 & 4.0 & 0.23 & $3.0^{\mathrm{b}}$ & $3.5^{\mathrm{b}}$ & $4.9^{\mathrm{a}}$ & 0.21 & ns & $* * *$ \\
\hline Scrotal fat & $0.48^{\mathrm{b}}$ & $0.56^{\mathrm{a}}$ & $0.37^{\mathrm{c}}$ & 0.03 & $0.3^{\mathrm{c}}$ & $0.4^{\mathrm{b}}$ & $0.6^{\mathrm{a}}$ & 0.03 & $* * *$ & $* * *$ \\
\hline
\end{tabular}

ANK - Ankole; AXB - Ankole-Boran; AXF - Ankole-Friesian.

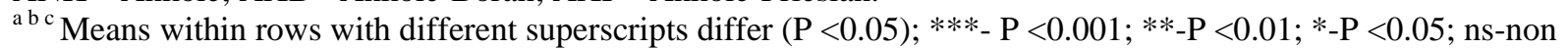
significant; s.e. - standard error of the mean; ${ }^{1}$ Total GIT comprised rumen, reticulum, omasum, abomasums, small and large intestine and caecum; ${ }^{2}$ Internal fat contained omensal fat, mesenteric fat, kidney fat and pluck fat.

\section{Acknowledgements}

The authors want to thank Danida Fellowship Centre for financial support of ENRECA project "Income Generation through Market access and improved Feed Utilization: Production of quality Beef and Goat Meat (IGMAFU-Meat)" under which this study was conducted.

\section{References}

Grimaud, P., Mpairwe, D., Chalimbaud, J., Messad, S., \& Faye, B., 2007. The place of Sanga cattle in dairy production in Uganda. Trop. Anim. Health. Prod. 39, 217-227.

Hatungumukama, G., Sidikou, D.I., Leroy, P. \& Detilleux, J., 2007. Effects of non-genetic and crossbreeding factors on daily milk yield of Ayrshire×(Sahiwal×Ankole) cows in Mahwa station (Burundi). Livest. Sci. 110, 111-117.

Huber, R., Baumung, R., Wurzinger, M., Semambo, D., Mwai, O. \& Winckler, C., 2008. Grazing, social and comfort behaviour of Ankole and crossbred (Ankole x Holstein) heifers on pasture in south western Uganda. Appl. Anim. Behav. Sci. 112, 223-234.

Jenet, A., Fernandez-Rivera, S., Tegegne, A., Yimegnuhal, A., Osuji, P.O. \& Kreuzer, M., 2004. Growth and feed conversion of Boran (Bos indicus) and Holstein_Boran heifers during three physiological states receiving different levels of a tropical diet. Livest. Prod. Sci. 89, 159-173.

Kabi, F., 2003. Nutritive evaluation and utilisation of Ipomea batatas vines, Glicidia sepium and cottonseed cake as protein supplements to bulls. Unpublished PhD, Makerere University, Kampala.

MAAIF, 2006. Summary of the National Agricultural Statistics. Ministry of Agriculture, Animal Industry and Fisheries. Retrieved. from http://www.agriculture.go.ug.

Mpairwe, D.R., Katongole, C., Bareeba, F.B., Mukasa-Mugerwa, E. \& Ebong, C., 2003. Effect of plane of nutrition on growth performance and carcass characteristics of growing Ankole, N'ganda, and crossbred (Friesian x Ankole) bulls and their potential for beef cattle fattening in Uganda. Paper presented at the 30th TSAP Scientific conference, 4H Centre-Tanga, Tanzania. 
Ndumu, D.B., Baumung, R., Wurzinger, M., Drucker, A.G., Okeyo, A.M. \& Semambo, D., 2008. Performance and fitness traits versus phenotypic appearance in the African Ankole Longhorn cattle: A novel approach to identify selection criteria for indigenous breeds. Livest. Sci. 113, 234-242.

Owens, F.N., Dubeski, P., \& Hanson, C.F., 1993. Factors that alter the growth and development of ruminants. J. Anim. Sci. 71, 3138-3150.

SAS, 2003. SAS User Guide Statistics, Version 9.1 edition. SAS Inc., Cary, N.C., USA.

Strydom, P.E., 2008. Do indigenous Southern African cattle breeds have the right genetics for commercial production of quality meat? Meat Sci. 80, 86-93.

Strydom, P.E., Frylinck, L., Van der Westhuizen, J. \& Burrow, H.M., 2008. Growth performance, feed efficiency and carcass and meat quality of tropical adapted breed types from different farming systems in South Africa. Aust. J. Exp. Agric. 48, 599-607.

Webster, A.J.F., 1986. Factors affecting the body composition of growing and adult animals. In: Symposium on comparative aspects of body composition of farm and laboratory animals, The Queen's University of Belfast, Bristol BSI87DU. pp. 45-53. 